\title{
A Private Philanthropic Foundation Case History*
}

\author{
Antonio Danieli* ${ }^{* *}$ Mario Di Nauta***
}

\begin{abstract}
Fondazione Golinelli has been established in Bologna in 1988 by the will of Marino Golinelli, a 95 years old entrepreneur and philanthropist, with the aim of promoting - with an integrated approach - education and training, spreading culture, and encouraging the intellectual and ethical growth of young people, the citizens of tomorrow.

Nowadays, it is a point of reference in the field of the dissemination of scientific culture. Its activities combine art with natural and social sciences, creating contacts between schools, universities, research, the world of business and the world of work.

One of the most important and strategic objectives is to offer to young people (above all school-age children, starting from early childhood) orientation and tools to permit them to grow responsibly, in civil and social terms, nurturing ethical behaviours to foster cohesive participation in a democratic society. Young people are capable of developing and adapting in an innovative and competitive way to an increasingly globalized world.

Since 2014, Fondazione Golinelli has begun working strongly also on entrepreneurial education and culture, through a new dedicated project area: Giardino delle imprese. Entrepreneurship is essential to train the adults of tomorrow and the nascent projects show the continuous and growing commitment to a better society.
\end{abstract}

Keywords: Education; Entrepreneurship; Innovation; Start-Up; Ecosystem; Philanthropy; Global Markets; Culture

\section{A Vision that Began in 1988}

Fondazione Golinelli is the unique case in Italy of a private non-profit foundation based on the model of the large American philanthropic foundations: concrete action, pragmatism, vision and efficacy in the implementation of projects make it an example of best practice among the foundations in the country.

\footnotetext{
* Invited Article

** Director, Fondazione Golinelli (direttore@fondazionegolinelli.it)

**** Educational and Organisational Office, Giardino delle Imprese (organizzazione@ giardinodelleimprese.it)
}

Edited by: ISTEI - University of Milan-Bicocca

ISSN: 1593-0319

Danieli, A., \& Di Nauta, M. (2015). A Private Philanthropic Foundation Case History, Symphonya. Emerging Issues in Management (symphonya.unimib.it), 3, 48. 
"I strongly believe in the importance of social responsibility. Through the foundation, I realized my desire to give back to the society a significant part of the fortune I have made, by means of projects which ignite young people's passion for culture and faith in the future" - Marino Golinelli.

Fondazione Golinelli was officially presented during the celebrations for the ninth centennial of the University of Bologna, and it was ratified by a Decree of the President of the Republic on 2 October 1989. Already in its first years of activity, Fondazione Golinelli stood out for its innovative projects, its orientation towards productive cooperation with the education system and the public administration, and its ability to circulate high-quality content through exhibitions, events, workshops, seminars and conferences.

Since July 2014 Fondazione Golinelli is an institution accredited by MIUR (the Ministry of Education, University and Research) for the training of school personnel. All of its training initiatives are recognized by the MIUR, and the participating teachers have the right to take time off for these programs, according to current regulations.

The future is what begins to happen in the very next moment. We live in extraordinary times: the exponential growth of knowledge, the spread of information, the multiplication of communication media offer unprecedented opportunities to all of us, and to the entire human beings.

To avoid being overwhelmed by the increasing level of complexity and the speed in which changes happen, there is a need to spread culture, promote creativity and nurture curiosity about the world and about ourselves, with a constant desire to learn. We have to know how to face art and science, reason and emotion, analysis and synthesis, brilliant theories and virtuous practices. We must never stop asking ourselves new questions, and seeking new answers. This is the logic behind the action of Fondazione Golinelli, offering everyone, in line with their abilities, new stimuli, tools and opportunities for knowledge, in the belief that the spread of knowledge can also reduce the possibility of conflict, favouring social cohesion and democratic participation.

Fondazione Golinelli pursue its objectives operating in collaboration with the leading institutions and the most authoritative academic, scientific and cultural partners on a local, national and international level.

\section{The Headquarters: Opificio Golinelli, 12 million euro Invested into the Future}

Opificio Golinelli, the citadel for knowledge and culture of Bologna, has opened the $3^{\text {rd }}$ October 2015 and is the new headquarter of Fondazione Golinelli and the home of its main educational, cultural and training activities.

Opificio Golinelli has been created thanks to a renewal project that has called for an investment of over 12 million euros. About 9000 square meters organized in independent pavilions and structures, connected by a system of promenades, gardens and plazas that recreate the configuration of urban public space, where are expected to welcome over 150.000 visitors per year. 
The location counts on several facilities: every project area have its own space and equipment with the latest technology; a multifunctional auditorium; equipped labs; rooms for workshops and interactive activities and various area for exhibitions.

For the opening, former president Marino Golinelli (currently honorary president) has announced a new long-lasting and visionary project: Opus 2065, with an investment of 30 additional million euro to the resources already in place and the purposes of training young people and teachers in a holistic approach that combines scientific and humanistic culture, creating a center for research on futuristic fields of knowledge and for the support of new ventures activities.

So far, Marino Golinelli has given over 81 million to the foundation, looking to 2065 not as an utopia but as a real purpose, in order to truly donate something tangible to today's generations.

\section{Education, Training and Creativity to Build a Society of Knowledge: The Six Main Project Areas}

The activities of Fondazione Golinelli have growth and expanded over the years both horizontally, involving new disciplines and new audience, and vertically, addressing new age groups and new social categories.

Today they are organized in six distinct project areas and involve pre-school children, students of elementary, middle schools, high schools and universities, but also teachers, families, scholars and specialists. The basic idea is that everyone has still something to learn. And they can learn it, if properly guided, whether they are three or ninety-nine years old, experts or absolute beginners. This is a holistic vision, aimed at incrementing the entire human and social capital of the country.

\subsection{The Six Project Areas}

Scuola delle idee: born in 2010, it is a space for the spread of scientific and artistic culture, knowledge and creativity, with a focus on children and young people from 2 to 13 years of age and their families. Scuola delle idee children's center organized by Fondazione Golinelli and the City of Bologna aims to stimulate creativity with a unified approach combining different scientific and humanistic disciplines. The physical space is innovative and plenty of facilities for experimentation, available to schools but also to adults and a wider audience, featuring demonstrations and exhibits, themed itineraries, and a section for kids (18 months - 5 years). Since the beginning, 130.000 participants have been involved and, in 2012, the school was named one of the ten best children's centers on a European level (www.scuoladelleidee.it).

Scienze in pratica: founded in 2000 thanks to the collaboration between Fondazione Golinelli, the University of Bologna and MIUR/USR Emilia-Romagna.

Scienze in pratica represents a reference point for research, training and informal education, and is a concrete, ongoing service for the school system, in training and education about the experimental sciences and more. The idea is to approach, train 
and keep up-to-date teachers and students, offering them an authentic hands-on laboratory experience with the help of lecturers and tutors, with the opportunity to use technologically advanced equipment and to participate in activities taken directly into schools thanks to mobile laboratories. Since 2009, each year, Scienze in pratica organizes summer camps on the life sciences for students who have attended the fourth and fifth years of secondary schools and want to deepen their knowledge of biotechnologies and life sciences, also with an eye on future choices of higher education. Since the creation, the area has involved about 156.000 participants and aim to become the largest "one-place" scientific-experimental laboratory in Italy (www.scienzeinpratica.it).

Scienza in piazza: since 2005, it is a format that transforms cities, towns or urban areas into temporary science centers. The aim is to bring citizens of all ages and cultural backgrounds, students and teachers from schools of every levels, into contact with science, art and culture, through personal involvement in workshops, exhibitions and interactive displays, encounters and debates. From 2009 to the present the program has focused on a different theme each year, addressed in all the events. In 2014 the orientation was a true Food Immersion, a preview of the themes of EXPO 2015 during the 17 days devoted to science and culture in the city of Bologna. With nine editions in the first eleven years, Scienza in piazza has involved almost 500.000 visitors (www.scienzainpiazza.it).

Educare a educare: a project area addressed to teachers and future teachers to help them innovate education and the school system. Educare a educare is a multi-year project extended nationwide and is focused on developing interactive methods in the field of science and technology, research on teaching and innovation in every school. The aim is a new way of teaching, focusing in particular on multidisciplinary activities, laboratory experimentation, new technologies, and in-depth cultural study on the links between research, science, innovation, technology and society.

Teacher training began in 2000 and has expanded thanks to the collaboration with several partners such us Ministry of Education, University and Research, Accademia Nazionale dei Lincei, University of Bologna and other research centres. Since 2013, almost 4.000 professors and school managers has been participating (www.educareaeducare.it).

Arte scienza e conoscenza: a project area that offers to a wide audience, opportunities for learning and discussion on individual scientific themes of timely importance and complexity. The activities develop along two complementary lines: on one hand, the organization and implementation of important exhibitions of art and science addressed to the general public; on the other hand, the organization of conferences directed to an audience of specialists and encounters for in-depth discussion open to everyone. Since 2007, almost 120.000 visitors took part in the related activities (www.artescienzaeconoscenza.it). 


\section{Giardino delle Imprese: Social Commitment to Entrepreneurial Culture and Innovation}

The sixth project area, created in May 2014 and managed by Trust Eureka, has the aim of offering to young people operative tools, dedicated spaces and specialists support to encourage and bring out entrepreneurial talents. Giardino delle imprese sets out to emphasize the individual gifts and particular abilities of young people in business, stimulating curiosity and passion and encouraging the development of innovative forms of creativity, entrepreneurial activities and achievement of project ideas. Giardino delle imprese is an informal school that fosters talents of young men and women, offering them a chance for a closer approach to entrepreneurial culture and innovation.

Currently, the area proposes 2 main educational path, one for high-school students and the other for university ones, both focused on high quality and excellence of teaching and participants. Soon, a $3^{\text {rd }}$ project, also based on university students, will take off. All the activities of Giardino delle imprese end up in a public weekend shared with all the stakeholders, the Maratona Opificio Golinelli - a 60 hours marathon dedicated to innovation and entrepreneurial themes.

Since the recent start, the project has involved 250 young people participating in programs of active learning, cooperation and experimentation (www.giardinodelleimprese.it).

"I would like to tell to the young entrepreneurs of tomorrow to be prepared for an unpredictable and changing world. They are the players of tomorrow." - Marino Golinelli.

\section{Conclusion: The Immediate Future}

In the last fifteen years, Fondazione Golinelli initiatives have reached more than 1 million persons and the new Opificio Golinelli is expected to welcome over 150.000 visitors per year, among students, professors, families, specialists, artists, experts, entrepreneurs, scientists, researchers and many more.

The headquarter has been created to ensure a strong contamination of knowledge, an holistic and multidisciplinary approach to education, an open and large laboratory of experimentations, a place to foster the combination of knowledge and know-how and a place for everyone, from kids to the elderly.

Recently, Fondazione Golinelli has broadened its range of activities, starting new and challenging projects, together with prestigious player such as the Italian Ministry of Education, University and Research, Expert System, Nòva24 (Il Sole24Ore weekly magazine focused on innovation and technology), the Italian Institute of Technology and the University of Bologna.

Discovery24 and Frontiere are two of these projects, which will take off in the coming months.

Discovery 24 will develop a searching system about operational information on the latest scientific news generated by the global scientific research in order to support businesses and companies. The semantic and artificial intelligence tools developed by Expert System, a Modena based company leader in the sector, will be constantly 
enriched by the work of researchers and journalists. The output, will be a high-tech journalism system with press reports for the business community, for both wellestablished and start-up companies, as well as for the entrepreneurial training field. Discovery24 has been selected to be co-financed for an amount of $530.000 €$ by Digital News Initiative Innovation Fund (digitalnewsinitiative.com), the Google's fund for digital innovation in journalism (the first round of funding awarded 27 million euros in 23 European countries).

Frontiere will be designed for the world of education and training and will result in the production of videos on the latest findings in nanotechnology research, life sciences and robotics, with the support of the best researchers in these fields. Frontiere is born with the aim to enhance the permanent and continuing training of teachers in order to promote innovation in the schools at a national level. The videos produced will have open access on the web, while the developed materials for both teachers and high school students, as well as for corporate training, will be available upon agreements. Moreover, it is in the works another new and significant project that will focus on university students and entrepreneurial education and will refer to Giardino delle imprese area.

Starting from a three-year agreement recently signed with the University of Bologna, Fondazione Golinelli will launch an entrepreneurial formative program completely based on students and their ideas and interests. The project comes as an excellent (and free) educational service in order to support students and the development of their business projects, including the phase of searching for seed funding.

The program will touch all the main aspects related to entrepreneurship and innovation, aiming to support interdisciplinary team of students on an ongoing basis, pursuing high quality of education and tailoring its activities on the real needs of the participants.

The program could end up in the already mentioned Maratona Opificio Golinelli, an entire weekend dedicated to these topics. Lastly, the project will have a dedicated location, the new Serre dei Giardini Margherita, an urban and innovative hub newly established in the city of Bologna.

\section{Bibliography}

Altuntas, C., \& Turker, D. (2015). Local or global: Analyzing the internationalization of social responsibility of corporate foundations. International Marketing Review, 32(5), 540-575.

Brondoni, S. M. (2015). Global Networks, Outside-In Capabilities and Smart Innovation, Symphonya. Emerging Issues in Management (symphonya.unimib.it), 1, 6-21

http://dx.doi.org/10.4468/2015.1.02brondoni

Franzoni, S., Gennari, F. (2013). School Networks and Sustainable Development, Symphonya. Emerging Issues in Management (symphonya.unimib.it), 2, 32-46 http://dx.doi.org/10.4468/2013.2.03franzoni.gennari

Gandini, G., Bosetti, L., Almici, A. (2014). Risk Management and Sustainable Development of Telecommunications Companies, Symphonya. Emerging Issues in Management (symphonya.unimib.it), 2, 16-29 http://dx.doi.org/10.4468/2014.2.03gandini.bosetti.almici 
Gnecchi, F. (2009). Market-Driven Management, Market Space and Value Proposition, Symphonya. Emerging Issues in Management (symphonya.unimib.it), 2, 33-45

http://dx.doi.org/10.4468/2009.2.04gnecchi

Lambin, J. J. (2009). Capitalism and Sustainable Development, Symphonya. Emerging Issues in Management (symphonya.unimib.it), 2, 3-9

http://dx.doi.org/10.4468/2009.2.02lambin

Mendel, S. C., \& Brudney, J. L. (2014). Doing good, public good, and public value. Nonprofit Management and Leadership, 25(1), 23-40.

Mosley, J. E., \& Galaskiewicz, J. (2015). The relationship between philanthropic foundation funding and state-level policy in the era of welfare reform. Nonprofit and Voluntary Sector Quarterly, 44(6), 1225-1254.

Quinn, R., Tompkins-Stange, M., \& Meyerson, D. (2014). Beyond Grantmaking Philanthropic Foundations as Agents of Change and Institutional Entrepreneurs. Nonprofit and Voluntary Sector Quarterly, 43(6), 950-968.

Salvioni, D. M., Bosetti, L. (2014). Sustainable Development and Corporate Communication in Global Markets, Symphonya. Emerging Issues in Management (symphonya.unimib.it), 1, 32-51 http://dx.doi.org/10.4468/2014.1.03salvioni.bosetti

Sargeant, A., \& Jay, E. (2014). Fundraising management: analysis, planning and practice. Routledge. 